\title{
OFFSHORE OPERATING AGREEMENTS
}

\author{
D. A. MacWILLIAM* and R. C. MUIR**
}

\begin{abstract}
The following article analyzes the offshore joint operating agreement in detail. Inter alia, the possible corporate forms a Canadian company could use, and their respective advantages and disadvantages, are discussed. The authors consider the new concepts and different provisions and procedures that are necessary to deal with the special problems of offshore operations. Operatorship, with its corresponding rights and obligations, is discussed with emphasis on whether or not a challenge clause should be included in the agreemint. Independent operations, and the subsequent determination of penalties, are reviewed. The authors discuss problems involved with dis. position of production, and in particular, the overlift-underlift clause. Other topics examined are offshore lease selection, sharing of platform costs, and arbitration clauses.
\end{abstract}

\section{INTRODUCTION}

This paper deals with concepts affecting joint venture operating agreements to be used in offshore areas both in Canadian and foreign waters. Costs of offshore operations are very much higher than onshore operations and foreign laws are more peculiar, or at least less familiar, than domestic laws. Accordingly, the agreements used by joint-venturers should be tailored to meet the new environment. Some clauses in these agreements are incorporated virtually unchanged from standard onshore operating agreements. Other onshore clauses are altered greatly and it is with these variations that this paper deals.

\section{PARTIES}

There are three basic corporate forms available to a Canadian company wishing to take part in offshore operations in a foreign country. In order of desirability from a commercial interest point of view, these are (i) Canadian subsidiary registered as a branch in the foreign jurisdiction, (ii) subsidiary incorporated in the foreign jurisdiction, and (iii) Canadian parent registered as a branch in the foreign jurisdiction.

The registration of the parent as a branch is listed at the bottom because it is prudent to conduct operations by way of a subsidiary so as to obtain the benefits of limited liability and it is desirable to avoid submission by the parent to the foreign taxing authority. Some foreign jurisdictions require incorporation in the country in which the operations are to be conducted as a condition precedent to holding a licence and in such cases only the middle course listed above is open. Unfortunately, incorporation in the foreign jurisdiction is often a tedious and confusing process, carrying with it undesirable capital deposit requirements:

The tax interests of the company would appear to demand that Canadian companies proceed by the least attractive, and often unavailable method, namely, registration of the parent as a branch. ${ }^{1}$ To the Department of National Revenue falls the task of interpreting the scribblings of the Department of Finance draftsmen and there is some confusion as to whether a Canadian company following courses (i) or

* D. A. MacWilliam, Senior Staff Solicitor, Mobil Oil Canada Ltd., Calgary, Alberta.

* R. C. Muir, Manager, Legal Department, Home Oil Company Limited, Calgary, Alberta.

'S. 66(4), The Income Tax Act, S.C. 1970-71, c. 63. 
(ii) above can obtain the modest write-offs which appear to be open to a Canadian company which follows course (iii). The new Minister of Finance has indicated that the problem is recognized. ${ }^{2}$

American, British, French, German, Italian and companies of other nationalities do not appear to be hobbled by taxing legislation enacted by their home governments. They invariably operate by way of subsidiary. Thus in a co-venturer situation the usual result is a group consisting of impecunious parties embarking on a very expensive operation. The dangers to which an operator of such a group is exposed are obvious.

The usual costs and expenses provisions of operating agreements in use in western Canada provide that the operator will initially advance the money and charge non-operators in accordance with participating interests. Also, the operator can bill non-operators for advances on a month-to-month basis. If a non-operator fails to pay the operator's billing, the operator can charge annual interest, at a specified rate or at $1 \%$ higher than the prevailing bank interest rate. Further, the operator has a right of set-off against sums owing to the non-operator from the operator and the operator can direct a purchaser of the non-operator's share of petroleum or natural gas to pay the proceeds to the operator. He can also bill the remaining non-operators for their participating interest share of the defaulting non-operator's debit. Finally, the operator can sue at law. These provisions may be adequate in an onshore situation where all parties have substantial assets. They are inadequate in offshore exploratory and development situations.

One way of meeting the problem is for the parties to arrange for each of their parent companies to guarantee the performance and payment of obligations and liabilities of their respective subsidiaries. Thus, the operator can look to some responsible entity for reimbursement. If, for good and valid reasons, a party cannot or will not give such a guarantee and later defaults on a billing from the operator, then the operator can bill other non-operators for a portion of the bill pursuant to the usual agreement provisions and upon any default on this secondary billing, the guarantee can be invoked.

A difficulty with respect to the guarantee route is with regard to third party liability stemming from matters such as pollution or ship collision. Parties may complain that guarantees might leave the parent companies open to large damage judgments. It is arguable that a judgment creditor cannot rely on an inter-party guarantee to get at the parent companies back of the operating subsidiaries. This is so where the parties are unanimous in their desire to avoid payment. However, if they are not unanimous, parties desiring to meet the judgment could force payment by the remaining parties through the guarantee route. Another aspect of the problem is that the usual form of offshore drilling contract requires the company to hold the contractor harmless from pollution claims. Further, where the operator is an assetless subsidiary, the contractor will demand a guarantee of performance from the parent of the operator. The prudent operator will make the parents of his coventurers agree to be jointly and severally liable on the guarantee to the contractor. He may also follow a similar course on contracts for hire of a freighter, workboats, helicopter and other equipment. This multiplication of documents can be avoided by the blanket guarantee route referred to above.

2 [1972] 3 H.C. Deb. 2020 et. scq. 
Another method of upgrading the usual operating agreement provisions is to divest a party of its interest in the licence on default of payment. A clause seeking to accomplish this should provide for forfeiture to be effective as of the date of default and for the defaulting party to do any and all things required to accomplish assignment to nondefaulting parties or, in the absence of government consent to such an assignment, to hold the divested interest for the benefit of the nondefaulting parties. However, it might be useful that the clause be concluded as follows:

The Parties hereby acknowledge and agree that the above forfeiture provisions are, in the nature of the oil and gas exploration business, reasonable and equitable and further hereby waive any and all rights which they have at law, in equity or by statute to relief against forfeiture where said provisions are invoked.

\section{WORK COMMITMENTS}

Offshore licences may be granted on bid acceptance which is equivalent to the familiar Alberta Crown Sale method of disposal. In other cases the licence will be granted upon completion of work commitment negotiations between the state and the companies such as the drilling of one well to a specified depth on the licensed area. Some states allow surrender of the licence after issuance and consider the work commitments as to drilling as merely intentions and not commitments. Other states regard the commitment as obligatory and, accordingly, the companies will have done some seismic before commitment. Where the state requires the drilling of a well it may also require the furnishing of a bank guarantee by some local branch of an international banking organization. Of course, the bank will require back-up by the parent company and by the parent company's Canadian bankers. The bank guarantee is payable to the state on demand with allegation of default under the licence. Bank guarantees should be avoided because of the onesided nature of the remedy in the case of a genuine dispute. An attempt should be made to convince the state that the reputation and standing of the company coupled with the right of the state to annul the licence on default affords the state sufficient protection.

Where the work commitment is a true obligation, the operating agreement must provide for decisions to be made by some of the parties with respect to matters relating to the drilling of the commitment well or wells. For example, in the case of a five-party agreement with each party owning a $20 \%$ participating interest, a vote of at least $60 \%$ should enable the parties to proceed for the joint account of all parties. Once the commitment is performed, further drilling or other operations would be subject to independent operations clauses (see infra). Where the drilling obligations are not true commitment obligations, then only seismic costs should be chargeable to the joint account on vote and the initial well should be, where there are dissenting parties, an independent operations well.

It is usual to exclude obligation commitment operations from the application of independent operations clauses. Care should be taken to allow independent deepening beyond commitment depth. The object is to bind all parties to contribute to drilling to commitment depth and to prevent 
any party from restraining the others from drilling deeper (and obtaining substantial penalty rights) pursuant to independent deepening notice.

\section{OPERATORSHIP}

Because of the alien and oftentimes dangerous environment that confronts him, the operator in an offshore operation is called upon to exercise many new skills and techniques and to conduct extensive research and planning. Only a company with considerable assets, both human and physical, can realistically assume the position of an operator in offshore operations. This principle applies, of course, to all joint operations but because of factors herein described, is of much greater importance offshore.

This brings us to the first question which we would like to consider -whether or not there should be a right on the part of the nonoperator to challenge the operatorship on the grounds that the nonoperator can operate the joint property in a more economic manner. In this connection we are not considering those instances where the operator must resign or be removed from his office for reasons of his bankruptcy; assignment for the benefit of creditors; disposing of all or a major portion of his interest in the joint property; or failing to remedy a default within the prescribed time. In addition, there is always the right of the operator to resign after serving a certain minimum period. The consequence of having a right of challenge in an offshore operating agreement must be appreciated fully in order to be able to weigh the advantages of having a right of challenge against the disadvantages which may occur as a result of an effective challenge.

The almost universal practice of relating a challenge notice to better economic standards may involve uncertainty and unrealistic results. An operator can always operate at less cost by curtailing his operations, but the result may not necessarily be that the property is administered more economically, and in any event the orderly development of the property would possibly be affected.

One factor which must be considered is the relative participating interests of the operator and the other parties in the joint property and their ability to carry on an offshore operation. Where the percentages of participating interest are divided more or less equally between all the parties including the operator, a challenge clause should probably be included because a non-operator is not likely to give a frivolous challenge notice as each party has to bear similar portions of the operating costs. However, where the operator has a significantly greater interest in the joint property than the non-operator and the agreement has a challenge clause, the non-operator knows full well that the operator would not allow him to act as operator and spend money which would be mainly the operator's. A challenge notice in this situation would force the operator to reduce his rates in accordance with the notice with the result that he would either operate the joint property thereafter at a loss or so curtail the operations that the joint property would not be operated in accordance with good oilfield practice. An alternative method of protecting the interests of all parties, including the operator, is to provide that challenges cannot become effective so as to result in change of the operator except upon an affirmative vote of a significant majority (in terms of interest) of all parties. 
Another problem which must be considered when deciding on the merits of including a right of challenge provision is that any change of operator, for whatever reason, will interfere with the orderly operation of the property. Where a particular company has been operating an offshore property for two years or more, it will have located a work force both on shore and on the offshore facilities; it will have entered into a multitude of service and supply contracts, to say nothing of drilling contracts; and it will have established important contacts with representatives of the many governmental departments involved in the operation. The additional costs resulting from a forced change of the operator together with the interruption of continuous operations may well outweight any possible advantages alleged by the challenging nonoperator.

To summarize, it is recommended that serious consideration be given either to deleting the challenge of operator provision from offshore joint operating agreements except where all parties thereto have similar interests and operating ability, or to improving same by including a requirement for a significant majority approval to affect a change of the operator. In drafting a joint operating agreement, a proper method must be established whereby the operator is able to charge to the joint account all his operating costs. Normal onshore methods are not realistic in an offshore operation.

Both the rights and duties of the operator and the accounting procedure provisions require amendment to take into account the logistics involved in an offshore operation conducted several thousand miles away from the operations headquarters of the operator. The operator in an offshore operation must carry out a great number of activities confined solely to that operation. These include arranging for drilling vessels, service and supply vessels, helicopters, stock piling of equipment and material, radio satellite locating equipment, construction of drilling and production platforms, etc. In northern and Canadian east coast waters, arrangements must be made to minimize hazards from icebergs, floe ice and pack ice.

All of these requirements involve the operator in a multitude of activities, many of which under an onshore agreement would be considered to be overhead items as they would not be carried out on the site of the operations, namely, the drilling vessel or the production platform. It is virtually impossible to determine in advance the extent of these costs with any degree of accuracy and arrive at a proper overhead amount.

In order to overcome this problem, a clause has been developed in some agreements which gives the operator the right to assign to and maintain on the production platform, and other facilities and on any land areas or properties used in or applicable to the joint operation, such technical, administrative and supervisory company personnel and outside consultants as may be necessary for the conduct of the operation. The clause provides further that the costs in connection with such personnel and consultants assigned to and directly engaged on such area of operations where their assignment is necessary for the efficient development of the joint operation will be a direct charge to the joint account. Corresponding changes must also be made to the accounting procedure to allow for the proper allocation of costs in accordance with such a clause. For want of a better name, this has been called the "task force" concept and is a realistic solution to this problem. 


\section{INDEPENDENT OPERATIONS}

Once the licence commitment operations have been performed, further drilling operations as well as whipstocking, reworking, plugging back and completing can be carried out for the account of some but not necessarily all of the parties. The basic business principle is that in cases of disagreement as to location, depth and other facets of operations. some of the parties should be able to proceed and the others should have the right not to be forced into paying for an operation in which they have no faith. Some corollaries are:

(i) that the party going independent must be successful in the operation;

(ii) that the party not participating must suffer a penalty if the independent party is successful and that the greater the risk undertaken and the greater the success achieved by the independent party, the greater will be the penalty suffered by the party not participating; and

(iii) that the independent party must not divest the non-participant of proven reserves by way of independent operations.

What are some of the provisions in vogue?

Where the drilling of a well is required to preserve title, any party may drill and upon well commencement the non-participants lose their interest in the lands (which would be forfeited if the well is not drilled). As for other wells, some agreements require that an independent drilling notice can only be given by a specified minority percentage in interest of the parties. The notice must specify well location, depth, commencement date and cost. It must set out details of any acreage or cash contribution pledged in support. In agreements where there is a penalty as to area to be lost by non-participants, the area must be specified. Independent drilling notices cannot be given for a certain period after completion of licence commitment drilling obligations nor where a well is being drilled on the licensed area nor by a party who has given a notice within the previous 225 days. A party wishing to join in the well may elect to join only to the extent of its participating interest or to the extent of its participating interest increased by a proportionate share of that of any other party failing to join in. The drilling parties can commence drilling only within 180 days of the notice of expiry date and once commenced the well must be drilled as set out in the notice.

Variable penalties can be applied to the non-drilling party depending upon (i) whether the well is an exploratory or a development well, and (ii) whether the well is successful and to what degree. A well three miles or more from a producing well would be an exploratory well. A well within three miles from a producing well but to be bottomed lower than the stratigraphic equivalent of the bottom hole of another well on the licensed area would be exploratory. Other wells would be development wells. Success may take two forms, namely, the discovery of oil or gas in commercial quantities or discovery in paying quantities. We feel that the usual definitions of these results are not sufficiently precise and prefer to specify actual quantities based on adequate testing-in the case of oil, in barrels, and in the case of gas, in cubic feet against specified back pressure with water limits and adequate hydrocarbon content.

An exploratory well encountering production in commercial quanti- 
ties may result in the non-drilling party losing its interest in a quarter of the entire licensed area. Where the same well encounters production in paying quantities, the non-drilling party may lose its interest in the well spacing unit. Both of these areas will have been specified in the original notice. Where spacing units are not provided for by government regulation, the definition in the operating agreement will cover the contingency for oil and gas wells by use of the relevant survey system.

Development well penalties may be predicated upon discovery in paying quantities only and may be financial only. A graduated form of penalty might be used. A penalty of eight times the amount which the non-driller would have paid had he participated might be levied out of production with respect to costs of drilling, testing and completing the well through Christmas tree; a six times penalty with respect to installing onshore and offshore equipment (including production platform) with recovery of operating costs to the drilling party. Some wells are plugged and not completed. Accordingly, the six times penalty might also apply to the drilling, testing and completing of the replacement well and to the onshore and offshore production equipment with respect thereto. Wells which do not encounter production at least in paying quantities do not earn penalty. Further provisions should be incorporated protecting non-drillers from losing an interest in existing producing formations or in formations below depth penetrated. Lastly, non-drilling parties are not entitled to obtain access or well information, in cases of financial penalty, until the penalty is paid out or, in cases of acreage penalty, ever.

Other clauses deal with independent deepening, whipstocking (other than normal whipstocking to overcome difficulties in the normal course of drilling), reworking and plugging back. The penalties in cases of deepening and whipstocking may be acreage or financial depending upon well location and success. The penalties in cases of reworking and plugging back are usually financial only and may not carry a requirement of success beyond mere completion for production. Further, the agreement may provide that parties participating in a well are not obligated to participate in completion operations beyond the casing point, i.e. the point at which the well has been tested to objective depth. The parties proceeding to complete may obtain a financial penalty upon mere completion for production.

The above provisions are neither standard nor universally acceptable in the offshore industry. Each agreement takes its own form. However, the North American industry concept of high penalties in high cost areas seems generally acceptable.

\section{DISPOSITION OF PRODUCTION}

Onshore joint operating agreements provide that each party may take and dispose of its share of the production and failing which the operator may take and dispose of it on the same terms as on the disposal of its own share. The right of the operator is restricted in time in that the operator can only enter into contracts for the sale of the other party's share for periods consistent with the minimum needs of the industry and in no event to exceed one year. The limitation on the authority of the operator is included to avoid having the joint operation classed as an association taxable as a corporation under the U.S. Internal 
Revenue Code. This method of disposing of joint production may be adequate to cover the handling of production in those areas where the production is prorated to market demand and allocated to the producers in each pool as no party can produce his own share of the pool at the expense of the other party.

However, in no offshore area of the world are there prorationing laws now in effect. Further, reserves discovered must be substantial in order to offset high offshore development costs. The mode of producing and marketing these reserves in a non-prorationing context assumes some importance.

A party to a joint operating agreement with respect to lands located in a Canadian or U.S. common law jurisdiction is a co-tenant and as such is able to separately produce from the joint lands and sell his share of the petroleum substances without the other party necessarily participating in the operation. However, he must account to the other party to the joint venture for its working interest shares of the proceeds from the sale of such production, less its shares of the producing and selling costs. ${ }^{3}$ Similar concepts appear to apply in other common law jurisdictions.

Consider the situation where a group of co-venturers consists of a mixture of major integrated companies and independent exploration and production companies. Each major has access to its refining and marketing complex as a means of disposal of production while the independent does not and must arrange for markets into non-owned refineries. The attitude of the major is that it cannot allow the independent to ride on its coattails. The attitude of the independent is that the agreement cannot be drafted so as to negate legal rights of the independent to an accounting for production taken. Various arguments can be mustered in support of each side but the end result may be that neither side can agree to any provision with respect to disposal of production. Further, where every party is reasonably confident of a market, logistics problems will prevent offtake of production on a mathematically regular basis. Accordingly, whether or not independent companies are involved, the desire of the major will be to include an overlift-underlift clause. The effect of this clause is to provide for orderly marketing and to negate co-tenancy rights.

The overlift-underlift clause first gives each party the right to take in kind and separately dispose of its share of the petroleum substances when produced and if this does not occur, then the clause provides that:

(i) the operator prepares periodic production or "lifting" programs, each covering a period not to exceed one year. The program contains a forecast on a monthly basis of the availability of each distinctive class of liquid petroleum substances at each delivery point in the producing area. Each program shall be prepared at least six months in advance of the particular period;

(ii) to the extent that one party does not elect to move its share of the available production as set out in the program, thereby becoming an underlifter, it shall within 30 days of receipt of the program, so advise the other party who then may elect to

3 Olisa, Legal Problems Arising Out of Co-ownership of Oil and Gas Leaschold Estate and Facilities, (1970) 8 Alta. L. Rev. 177; and Muir, Split Sales of Gas, (1971) 9 Alta. L. Rev. 496. 
accept such production or any portion thereof in excess of its share, thereby becoming an overlifter;

(iii) to the extent that the underlifted oil under subclause (ii) is not accepted by the other party and the operator, the operator shall reduce the rate of production to balance out the underlift;

(iv) the underlifter may elect to recoup his underlift in subsequent periods out of $10 \%$ of the available production at the delivery point until the parties are in balance once again, provided that an underlifter may not so recoup from such $10 \%$ share of the available production in any period an amount which is greater than the volume obtained by multiplying the underlift volume by a fraction, the numerator of which is the number of days in the period and the denominator is 365 ;

(v) once the lifting program has been established by the operator as above described and a party does not lift his share of the production as scheduled by the operator in its lifting program, the same principles apply except that the underlifter may not elect to recoup any of the underlift after five years from the end of the particular period, with the result that the right to recover such underlift thereafter goes back to joint account production;

(vi) if a party fails to lift and dispose of his share of production as he agreed to do under the approved lifting program the other party has the right to lift and dispose of it and to deduct therefrom, as compensation for the cost of handling the same, $20 \%$ of the actual realization netted back to the delivery point and credit such remaining amount to the non-lifting party's account;

(vii) royalty and production-related costs are allocated to the parties on the basis of their relative lifting and all other costs including labour, transportation, etc. and overhead are paid by the parties on the basis of their relative participating interests in the joint venture;

(viii) gas and liquids produced with gas are not subject to the provisions of the overlift-underlift clause.

The independent company will prefer a disposition of production clause which allows each party to take in kind its share of production but provides that where a party does not take in kind the operator will endeavour to sell the same at fair market value. The clause will further provide that no party will be entitled to take production so as to obtain its share until all parties, or the operator on their behalf, have made arrangements for the sale of their respective shares of production as and when produced. This clause effectively provides for orderly marketing and preserves or creates co-tenancy rights.

\section{PLATFORMS}

Drilling-production platforms serve a dual purpose in providing a base from which development wells can be drilled and to or through which production can be taken. Recently British Petroleum announced development plans for the Forties field in the U.K. North Sea including the drilling of 60 development wells from two 560 foot high platforms costing $\$ 24$ million each. A 115 mile submarine pipeline will carry 
crude from the platforms to the coast of Scotland and from there a 140 mile pipeline will carry crude to BP's Grangemouth Refinery. The cost of development, exclusive of development drilling costs, is estimated at $\$ 400$ million plus.

Many offshore operating agreements make provisions for platform construction. The simplest provision is that if the parties cannot agree upon construction of gathering lines, pipelines, delivery terminals or any other production facilities (including drilling and production platforms) beyond the wellhead, any one or more may construct and will own the said facilities. Whenever the capacity of the facilities exceeds the requirements of the owners they must offer terms for use of the excess capacity by the non-owning co-venturers. A variation on this theme requires a non-owner, as a condition precedent to his right to participate in drilling, deepening or other operation with respect to a well from a platform, to purchase an interest in the platform (at penalty rates) from the owners. The quantity of interest purchased is such that the nonowner will obtain an interest in the same proportion as its participating interest under the operating agreement bears to the sum of the participating interests of the parties participating in the well and the parties owning an interest in the platform all with a proviso that no change in platform ownership will reduce the interest of any party in a platform to less than its participating interest. Where a party never participates in a well operation from a platform yet owns an interest in a well, penalty rates are recoverable out of production from wells producing or benefiting from the platform. Capital cost additions are borne by the parties in proportion to platform ownership and operating costs are allocated to wells using the platform.

Another agreement might provide that any party may propose the construction of a platform and if a non-joiner later wishes to join in the drilling, deepening, etc. of a well from the platform then he must pay the platform owners either in cash or out of production from the well a penalty based on his share of original platform construction cost.

Another agreement might provide for a well by well cost adjustment. The first well drilled or produced from the platform is charged with all platform costs, i.e. the parties owning the well bear the costs in proportion to their interest in the well. A depreciation account (longterm declining balance at fixed rate) is set up and each subsequent well has allocated to it a fraction of the depreciated cost based on the total number of wells drilled.

Rapidly changing offshore completion and production technology and the high costs involved leaves one to suspect that platform costs hitherto in use may not be entirely adequate. There is an onshore industry tradition that operating agreements stop at wellhead completion and matters relating to pipelines and production facilities can safely be left to competitive producing operations or to future negotiation of unitization agreements. Our difficulty is that, as indicated above, the offshore platform is a device for both development drilling and production operations and, accordingly, provisions relating to its construction and ownership should be made. 


\section{CANADIAN OFFSHORE LEASE SELECTION}

One clause in offshore joint venture agreements which requires special consideration is the lease selection clause which sets forth the procedure under which lands are selected for lease out of federal permits. While our discussions on this clause relate to the federal regulations and procedures, it is recognized that ownership and jurisdictional claims on the offshore areas have been advanced by the Atlantic Provinces. The Province of British Columbia continues to claim similar rights to its offshore seabed notwithstanding the ruling of the Supreme Court of Canada to the contrary. ${ }^{4}$

The Canada Oil and Gas Land Regulations, ${ }^{5}$ issued under the Territorial Lands Act, ${ }^{6}$ set forth the requirements for the conversion of lands held under federal permits to oil and gas leases. It is not the intention of this paper to set forth in detail the manner in which lands may be selected for lease or to discuss the qualifications required of an applicant for leases under the Canada Oil and Gas Land Regulations. Suffice it to say that the Regulations provide that the permit holder may on his own initiative, or shall, if required by the Minister, select for lease up to $50 \%$ of the lands in his permit, provided that the land blocks he selects have certain maximum dimension and are located in a certain manner each to the other. ${ }^{7}$

The permit holder is permitted under the regulations to select land blocks for lease having greater maximum dimensions but in such case the total lands which he may obtain for lease from the permit is reduced to $40 \% .^{8}$ There must be a corridor of non-leased land surrounding each lease ${ }^{9}$ and the problems inherent in the handling of this acreage are discussed later in this paper.

The Canada Oil and Gas Land Regulations are in the process of being amended at the time of preparation of this paper, but following a series of meetings between representatives of government and industry it appears that the present principles of the government with respect to the selection of lands for lease out of permits will not be altered radically in the new regulations.

There are many different ways in which leases may be selected out of permits, but it appears that the procedures do not differ radically from those for lease selection out of federal permits for onshore areas. It must be recognized at the outset that the lands held under permit in an offshore joint operation may cover millions of acres and at the point in time when under the regulations the holders are required to select lands for lease the extent of the exploration operations on the lands may be relatively limited and the likelihood of having discovered commercial production is very low. In order to evaluate the permit lands in an effort to select those portions having the best potential, a great deal of interpretive evaluation must be made. In addition, other physical factors such as sea depths and location of iceberg "fairways" may influence decisions.

- In The Matter Of A Reference By. The Governor General In Council Concerning The Ownership Of And Jurisdiction Over Offshore Mineral Rights As Set Out In Order In Council P.C. 1965.70 Dated April 26, 1965 (1967) S.C.R. 792. Sec also statements made by Prime Minister, and Department of Energy. Mines and Resources in Lewis and Thompson, 1 Canadian Oil and Gas, para. $29 \mathrm{~B}$.

s S. 3, Canada Oil and Gas Land Regulations, SOR/61-253, (1961) 95 Canada Gazette (Part II) 805, June 6, 1961 , as amended.

6 Territorial Lands Act, R.S.C. 1970, c. T-6.

7 Canada Oil and Gas Land Regulations, supra, n. 5 at 8.56.

- Id. 8. 60(3).

Id. 8. 60(2). 
The result is that there will likely be a difference of opinion between the participants as to the lands to be selected for lease. Therefore, it is submitted that there is need for a more detailed lease selection clause in offshore joint venture agreements than in the case of similar agreements for land operations.

The lease selection clauses generally provide that the operator of the joint operation has the obligation to submit to all parties to the agreement, within a certain number of days prior to selection date, a proposed nomination of the permit lands to be selected for lease, and if all of the parties agree with this proposal, that is the end of the problem. The operator then proceeds with the approved nomination and leases will issue in the names of the parties in accordance with their working interests in the permit. However, if there is agreement on only a portion of the lands proposed for nomination many clauses provide that the operator then proceeds with a revised nomination for the joint account of the parties covering such portion. As to the remaining lands obtainable for lease, on which agreement is not reached, many clauses provide for alternate selection of the lands on which agreement was not reached by each party, followed by a selection for the joint account of those lands agreed to. Any lands remaining are then obtainable for the account of the party who nominated them.

Where the ownerships of the permit are such that one party holds at least two-thirds of the working interest therein, then there is justification for the drafting of the alternate selection provision, to provide that the party holding the larger interest would be entitled to nominate a larger block of acreage. In this way, the party having the majority interest has a greater control over the forming of lease selection patterns, a very important consideration, particularly when planning lease selection in offshore exploration areas.

Once the permit holders have completed their initial selection of leases for the permit, the regulations vest the Minister with the power, on application by the permit holders, to grant leases (hereinafter referred to as "additional royalty leases") to the permit holders covering the remaining unselected permit lands (hereinafter called "Crown corridor lands"). ${ }^{10}$ The manner in which the Minister has until recently been exercising such powers is set forth in Oil and Gas Order 1-1961.11 The additional royalty leases resulting from such applications provide for an extra royalty payable to the Crown from the production of oil in addition to the normal royalty reserved by the Crown allocated to the Crown corridor lands, under the oil and gas leases.

When production commences from a pool and a portion of the pool extends into Crown corridor lands, a tract factor for such lands must be negotiated between the holders of the oil and gas leases covering the other portion of the pool and the Minister. This will result in a percentage of the pool's total production being subject to the reservation of the additional royalty.

Earlier in this paper reference was made to the situation where the maximum percentage of lands which could be nominated for oil and gas leases could be reduced from $50 \%$ to $40 \%$ through the selection of larger blocks of acreage on lease selection. Because of this possibility, many lease selection clauses provide that when the parties are in the process

10 Id. 8. 58.

$"$ Oil and Gas Order No. 1-1961, SOR/61-461, 95 Canada Gazette (Part II) 1619, Nov. 8, 1961, as amended. 
of making alternate nominations of land for inclusion in oil and gas leases no party will make a nomination which will result in such a reduction of total acreage.

Because of the very large volume of reserves necessary to render an offshore production operation economically viable, it will be necessary in most cases for the holders of the permit to acquire the Crown royalty lands by additional royalty leases in order to protect their interests and avoid competitive operations in the pool.

When the Federal Government announced in 1970 that it would be bringing forth new regulations to supplant the Canada Oil and Gas Land Regulations, it revoked Oil and Gas Land Order No. 1 of $1961,{ }^{12}$ with the result that there is no real assurance that the new regulations will give similar powers to the Minister. However, it is expected that the new regulations will contain a provision similar to that of section 58 of the regulations and that the operating problems incidental to the selection of Crown corridor lands for additional royalty leases will continue.

In many joint venture agreements, the manner of selecting Crown corridor lands, failing agreement, is virtually the same as for the original selection of lands for oil and gas leases. However, there is some doubt as to whether there should be any provision in the clause which would allow any Crown corridor lands to be held by less than all parties without prior mutual agreement.

\section{ARBITRATION}

Arbitration clauses spring from the desire of the parties to avoid litigation-its expense, delays and evidentiary quagmires. However, the general oil industry attitude in Canada is that while there is a limited place for arbitration (e.g. gas sales contract reserve redeterminations) there are serious disadvantages arising out of the lack of independence and experience of the arbitrators, expense, delays and the likelihood that the loser will, in the end, go to the Courts to set the award aside. The onshore Canadian industry by and large avoids arbitration clauses.

In offshore situations parties of three or four nationalities may operate in a country foreign to all parties. While we prefer that disputes be governed by the laws of Alberta and decided by the Courts of Alberta, our American and European co-venturers do not agree. Usually the laws and Courts of England are made the governing laws and forum of the agreement. However, the parties usually feel that before a dispute becomes entangled in the English legal system it would be better for an arbitration to be held whereby the dispute might be ended and if it is not ended by arbitration the reasoning of the arbitrator might have some persuasive effect upon Courts unfamiliar with the industry.

An example of an arbitration clause is:

In case any dispute or difference shall arise between the Parties or any of them as to the construction of this Agreement or as to any matter or thing of whatsoever nature arising out of or in connection with this Agreement, then such dispute or difference shall be and is hereby referred to arbitration and final decision under the Rules of Arbitration then obtaining of the International Chamber of Commerce. The arbitration shall be by three arbitrators appointed in accordance with the said Rules. The place of arbitration shall be 
London, England. The award or decision of the arbitrators shall be final and binding on the parties to the arbitration. No right of action shall accrue to any Party in respect of any said dispute or difference with another Party or Parties until after the dispute or difference has been decided upon by the arbitrators pursuant to arbitration hereunder.

The last sentence is what is known as a Scott v. Avery ${ }^{13}$ clause. The parties to a contract cannot oust the jurisdiction of the Courts to settle contractual disputes. However, they may agree that no right of action can accrue in the dispute until the arbitrator's decision. While the English Courts have jurisdiction not to stay proceedings, ${ }^{14}$ it is said that where the contract contains the Scott v. Avery provision "a stay can seldom usefully be refused". ${ }^{15}$

13 Scott v. Avery (1856) 5 H.L.C. 811, 10 E.R. 1121. See also Deuterium Ltd. v. Burns and Roe Ltd. (1972) 21 D.L.R. (3d) 568 .

14 Arbitration Act 1950, (Imp.) 14 Geo. 6, c. 27, s. 25(4).

13 Russell on Arbitration 160 (18th ed., 1970). 